\title{
PRIMARY TUMOR LYMPHOVASCULAR INVASION NEGATIVELY AFFECTS SURVIVAL AFTER COLORECTAL LIVER METASTASIS RESECTION?
}

\author{
Invasão angiolinfática no tumor primário compromete a sobrevida após ressecção de metástases hepáticas colorretais?
}

\author{
Renato Gomes CAMPANATI ${ }^{1 \oplus}$, João Bernardo SANCIO ${ }^{1 \oplus}$, Lucas Mauro de Andrade SUCENA ${ }^{1 \oplus}$, Marcelo \\ Dias SANCHES ${ }^{1 \oplus}$, Vivian RESENDE $^{1 \oplus}$
}

\begin{abstract}
Background: About $50 \%$ of the patients with colorectal adenocarcinoma will present with liver metastasis and $20 \%$ are synchronic. Liver resection is associated with improvement in survival in comparison to chemotherapy alone. Aim: To analyze the overall survival in patients submitted to liver resection of colorectal cancer metastasis and prognostic factors related to the primary and secondary tumors. Methods: A retrospective analysis of a prospectively maintained database regarding demographic, primary tumor and liver metastasis characteristics. Results: There were 84 liver resections due to colorectal cancer metastasis in the period. The 5 -year disease-free and overall survivals were $27.5 \%$ and $48.8 \%$ respectively. The statistically significant factors for survival were tumor grade $(p=0.050)$, lymphovascular invasion $(p=0.021)$, synchronous metastasis $(p=0.020)$, as well as number $(p=0.004)$, bilobar distribution $(p=0.019)$ and diameter of the liver metastasis over $50 \mathrm{~mm}(p=0.027)$. Remained as independent negative predictive factors: lymphovascular invasion ( $\mathrm{HR}=2.7 ; \mathrm{Cl} 95 \% 1.106-6.768 ; p=0.029)$, synchronous metastasis $(\mathrm{HR}=2.8 ; \mathrm{Cl} 95 \%$ 1.069-7.365; $p=0.036)$ and four or more liver metastasis ( $H R=1.7 ; C l 95 \% 1.046-2.967 ;$ $\mathrm{p}=0.033$ ). Conclusion: The resection of liver metastasis of colorectal adenocarcinoma leads to good survival rates. Lymphovascular invasion was the single prognostic factor related to the primary tumor. Synchronous disease and four or more metastasis were the most significant factors related to the secondary tumor.

HEADINGS: Colorectal neoplasms. Neoplasm metastasis. Prognosis. Survival analysis.
\end{abstract}

RESUMO - Racional: Cerca de metade dos pacientes com adenocarcinoma colorretal apresentará metástases hepáticas. Apesar da superioridade do tratamento cirúrgico, os pacientes com elas compõem um grupo muito heterogêneo. Objetivo: Descrever o impacto de fatores relacionados ao tumor primário e ao secundário na sobrevida após ressecção de metástases hepáticas colorretais. Métodos: Análise retrospectiva de base de dados mantida prospectivamente de pacientes operados. Resultados: Foram realizadas 84 hepatectomias para ressecção de metástases hepáticas de adenocarcinoma colorretal em 73 pacientes no período. A sobrevida global e livre de doença em cinco anos foram de $48,8 \mathrm{e}$ $27,5 \%$, respectivamente. Os principais preditores de sobrevida foram grau de diferenciação $(p=0,050)$ e invasão angiolinfática $(p=0,021)$ do tumor primário, metástases sincrônicas $(p=0,020)$, número $(p=0,004)$, distribuição bilobar $(p=0,019)$ e diâmetro máximo maior que $50 \mathrm{~mm}(p=0,027)$ dos nódulos hepáticos. Foram significativos a presença de invasão angiolinfática ( $H R=2,7 ;$ IC 95\% 1,106-6,768; $p=0,029)$, metástases sincrônicas (HR=2,8; IC $95 \% 1,069-7,365 ; p=0,036)$ e número de nódulos hepáticos igual ou superior a quatro ( $H R=1,7 ;$ IC 95\% 1,046-2,967; $p=0,033)$. Conclusão: A ressecção de metástases hepáticas de adenocarcinoma colorretal proporciona melhora da sobrevida e os principais fatores prognósticos foram a invasão angiolinfática no tumor primário, metástases sincrônicas e quatro ou mais nódulos hepáticos.

DESCRITORES - Neoplasias colorretais. Metástase neoplásica. Prognóstico. Análise de sobrevida.

\begin{tabular}{|c|c|c|c|}
\hline Variable & HR & $\mathrm{Cl} 95 \%$ & $\mathrm{p}$ \\
\hline \multicolumn{4}{|c|}{ Primary tumor } \\
\hline $\begin{array}{l}\text { Lymphovascular invasion } \\
\text { - None } \\
\text { - Present }\end{array}$ & $\overline{2.7}$ & $1.106-6.768$ & 0.029 \\
\hline \multicolumn{4}{|l|}{ Secondary tumor } \\
\hline $\begin{array}{l}\text { CRLM classification } \\
\text { - Synchronous } \\
\text { - Metachronous }\end{array}$ & $\begin{array}{c}2.8 \\
-\end{array}$ & $1.069-7.365$ & 0.036 \\
\hline $\begin{array}{l}\text { Number of nodules } \\
\cdot<4 \\
==4\end{array}$ & $\begin{array}{c}- \\
1.7\end{array}$ & $1.046-2.967$ & 0.033 \\
\hline
\end{tabular}

Central message

Lymphovascular invasion in the primary tumor is a worse prognostic factor for survival after colorectal liver metastasis surgical resection.

\section{Correspondence:}

Renato Gomes Campanati

E-mail: renatogcampanati@gmail.com

campanati@ufmg.br
Financial source: none

Conflict of interest: none

Received for publication: 21/07/2020

Accepted for publication: 09/10/2020 
INTRODUCTION

t is expected that about $50 \%$ of the patients with colorectal adenocarcinoma will present with liver metastasis, 20\% being diagnosed synchronous with the primary tumor ${ }^{3,6,8,28}$. Whenever feasible, liver resection presents with a 5-year overall survival between $24 \%$ and $64 \%$ in comparison with $10 \%$ to $11 \%$ of systemic chemotherapy alone ${ }^{1,9,10,13,19,21,22,23,30}$. Currently, patients with technically resectable nodules, a sufficient liver remnant, no or limited extra-hepatic disease and those considered fit to be submitted to major abdominal surgery are considered candidates for resection, though this accounts for only $20 \%$ of all metastatic patients 22,27

The main prognostic factors for overall survival after hepatic resection of colorectal metastasis are based on classical papers published between 1960 and 20009,10,13,18,21. However, more recent publications failed to demonstrate adequate accuracy of these variables in current population ${ }^{13,21,27}$. Much of this disparity is attributed to widespread and improvement in chemotherapy, better patient selection and advancements in surgical techniques. Besides that, a great number of these prognostic factors are related to the hepatic disease and not to the primary tumor.

The aim of this study was to describe the overall survival in patients submitted to resection of colorectal liver metastasis (CRLM) and to describe predictive prognostic factors related to the primary and secondary tumors.

METHOD

A retrospective analysis of a prospectively maintained database of patients with CRLM submitted to resections with curative intent between January 2007 and August 2018 in the Hepatopancreatobiliary Unit at Hospital das Clínicas, Federal University of Minas Gerais, Belo Horizonte, MG, Brazil, a major public tertiary oncological center in Brazil. This study was approved by the institutional review board of the university (CAAE- 0913591260000 ).

The exclusion criteria were any histologic type other than adenocarcinoma, hepatic resection due to contiguous involvement of the liver by the primary tumor and patients submitted to surgery without curative intent.

The classification of the American Joint Committee on Cancer (AJCC, $8^{\text {th }}$ edition, 2017) was used for staging and the primary tumor were also described regarding tumor differentiation, perforation, lymphovascular and perineural invasion. Synchronous metastases were those detected simultaneously or within six months of the diagnosis of the primary tumor and the size was reported according to the pathology measurement ${ }^{24}$. The resection of four of more liver segments was considered a major hepatectomy. Postoperative complications were reported according to the Clavien-Dindo classification.

\section{Statistical analysis}

Categorical variables were described as frequencies and continuous variables with minimum and maximum, mean, median, standard deviation and interquartile range. The Chi-Square and Fisher exact test were used to test for homogeneity between variables. Survival analysis was performed with the Kaplan-Meier method and the log-rank test used to analyze differences between survival curves. To compare variables with survival a multivariate analysis was taken using those with a $p=0,20$ after univariate analysis and expressed as Hazard Ratio (HR). In all analysis a $p$ value $<0,05$ was considered significant. Statistical analysis was performed using the IBM SPSS ${ }^{\circledast}$ V23.0 (Chicago, IL, USA).

RESULTS

In the given period, 73 patients were submitted to 84 liver resections of CRLM. Median follow-up was 44 months (3-140), with predominance of women $(n=50 ; 68.5 \%)$, median age of 54 years (28-80) and without family history of colorectal cancer $(n=60$; $82.2 \%$, Table 1). The 5-year disease-free and overall survivals were $27.5 \%$ and $48.8 \%$ respectively, with a median survival of 55 months.

Regarding the primary tumor, most cancers were located on the left colon $(n=54 ; 73.9 \%)$, with a T3 stage $(n=44 ; 60.3 \%)$ and positive nodes $(n=46 ; 63.0 \%)$. Well or moderately differentiated adenocarcinomas were the most frequent histology $(n=60 ; 82.2 \%)$, with lymphovascular $(n=34 ; 46.6 \%)$ and perineural invasions $(n=36$; 49.3\%) present in almost half of the cases (Table 1).

Regarding the liver metastasis, most of them were synchronous $(n=53 ; 72.6 \%)$, singlenodules $(n=43 ; 58.9 \%)$, with unilobar distribution $(n=54 ; 74.0 \%)$ and a median size of $40 \mathrm{~mm}$ (1-110, Table 1).

The majority was submitted to neoadjuvant chemotherapy $(n=65 ; 89.0 \%)$ and minor hepatectomies $(n=38 ; 52.1 \%)$. In eight cases $(11.0 \%)$ the colorectal and liver resections were performed simultaneously and in another seven (9.6\%) the hepatic resection was done in a two-stage procedure (Table 2). The mean length of hospital stay was five days (3-30), with a reported complication rate of $24.7 \%$, the majority being minor (17.8\%) and with no postoperative mortality (Table 2).

The most important prognostic factors related to survival after univariate analyses were: high tumor grade $(p=0.050)$ and lymphovascular invasion $(p=0.021)$ in the primary tumor and synchronous metastasis $(p=0.020)$, four or more hepatic nodules $(p=0.004)$, bilobar distribution $(p=0.019)$ and a diameter of $50 \mathrm{~mm}$ or greater ( $p=0.027$, Table 3$)$.

After multivariate analysis, the only factor related to the primary tumor that remained statistically significant for worst prognosis was presence of lymphovascular invasion, with a HR of 2.7 ( $\mathrm{Cl}$ 95\% 1.106-6.768; $\mathrm{p}=0.029$ ). Regarding the secondary tumor, synchronous metastasis and four or more nodules were also significant (Table 4).

\section{DISCUSSION}

The 5-year overall survival rate following liver resection for CRLM has improved from 24\% to up to $64 \%$ over time $19,10,13,19,21,22,23,30$. The surgical treatment of CRLM in the present study presents with a 5 -year overall survival of $48.8 \%$ and the most important prognostic factors after multivariate analysis were lymphovascular invasion in the primary tumor, CRLM diagnosed within six months of the colorectal cancer and the presence of four or more nodules.

Colorectal tumor location has been pointed out as an important prognosis factor for both localized and metastatic patients ${ }^{4}$ mainly because of singularities in pathological and molecular phenotypes and, consequently, different chemotherapy treatment response. In this study, the survival difference between right and left colon cancer (5-year overall survival of $40.1 \%$ and $52.7 \%$, respectively) did not prove to be statistically significant after univariate analysis $(p=0.282)$. Although a retrospective cohort of 221 patients in 2018 corroborate this finding, two recent metaanalysis showed a worse prognosis of right sided colon cancer with a HR of up to $1.39(\mathrm{Cl} 95 \% 1.28-1.51 ; \mathrm{p}<0,001)^{12,15,25,29,31}$. On the other hand, Yamashita et al. ${ }^{30}$ demonstrated that KRAS gene mutational status was an independent survival prognostic factor regardless of primary tumor location in patients submitted to resections of CRLM.

The $T$ and $\mathrm{N}$ stages are also frequently considered prognostic factors of colorectal adenocarcinoma. The nodal stage is presenton the three classical prognostic scores for CRLM treatment (Nordlinger, Fong and Basingstoke index), but a paper by Reissfelder et al. ${ }^{22}$ proposed to validate these factors in a current patient cohort and failed to demonstrate its reproducibility $7,9,18,21$. The lymph node stage is a highly variable factor that can be influenced by a number of features such as patient age, immune response, primary site and, specially, neoadjuvant therapy, much more commonly used nowadays ${ }^{7}$. Therefore, in resemblance to the primary tumor location, it is unclear whether nodal status has a significant relation 
TABLE 1 - Demographics and colorectal tumor factors in patients with CRLM submitted to liver resection with curative intent

\begin{tabular}{|c|c|c|}
\hline Variable & n (\%) & $p^{*}$ \\
\hline $\begin{array}{l}\text { Age } \\
\text { - Median (min-max) }\end{array}$ & $54(28-80)$ & 0.058 \\
\hline $\begin{array}{l}\text { Gender } \\
\cdot \text { Female } \\
\cdot \text { Male }\end{array}$ & $\begin{array}{l}50(68.5) \\
23(31.5)\end{array}$ & 0.089 \\
\hline \multicolumn{3}{|l|}{ Primary tumor } \\
\hline $\begin{array}{l}\text { Location } \\
\cdot \text { Right-sided } \\
\cdot \text { Left-sided }\end{array}$ & $\begin{array}{l}19(26.1) \\
54(73.9)\end{array}$ & 0.111 \\
\hline $\begin{array}{l}\text { T stage } \\
\cdot \text { T0 } \\
\cdot \text { T1 } \\
\cdot \text { T2 } \\
\cdot \text { T3 } \\
\cdot \text { T4 } \\
\cdot \text { Missing }\end{array}$ & $\begin{array}{c}1(1.4) \\
1(1.4) \\
8(11.0) \\
44(60.3) \\
16(21.8) \\
3(4.1)\end{array}$ & 0.214 \\
\hline $\begin{array}{l}\mathrm{N} \text { stage } \\
\cdot \mathrm{N} 0 \\
\cdot \mathrm{N} 1 \\
\cdot \mathrm{N} 2 \\
\cdot \mathrm{NX} \\
\cdot \text { Missing }\end{array}$ & $\begin{array}{l}21(28.8) \\
23(31.5) \\
23(31.5) \\
3(4.1) \\
3(4.1)\end{array}$ & 0.970 \\
\hline $\begin{array}{l}\text { Tumor differentiation } \\
\text { - Well/moderate } \\
\text { - Low/signet ring cell } \\
\text { - Missing }\end{array}$ & $\begin{array}{c}60(82.2) \\
6(8.2) \\
7(9.6)\end{array}$ & 0.121 \\
\hline Lymphovascular invasion & $34(46.6)$ & 0.078 \\
\hline Perineural invasion & $26(35.6)$ & 0.042 \\
\hline $\begin{array}{l}\text { CEA (ng/ml) } \\
\cdot \text { Median (min-max) }\end{array}$ & $11(0.2-489)$ & 0.004 \\
\hline \multicolumn{3}{|l|}{ Liver metastasis } \\
\hline $\begin{array}{l}\text { CRLM classification } \\
\text { - Synchronous } \\
\text { - Metachronous }\end{array}$ & $\begin{array}{l}53(72.6) \\
20(27,4)\end{array}$ & 0.007 \\
\hline $\begin{array}{l}\text { Number of nodules } \\
\cdot 1 \\
\cdot 2-3 \\
\cdot=4\end{array}$ & $\begin{array}{l}43(58.9) \\
17(23.3) \\
13(17.8)\end{array}$ & 0.012 \\
\hline $\begin{array}{l}\text { Distribution } \\
\text { - Unilobar } \\
\text { - Bilobar }\end{array}$ & $\begin{array}{l}54(74.0) \\
19(26.0)\end{array}$ & 0.002 \\
\hline $\begin{array}{l}\text { Diameter (mm) } \\
\text { - Median (min-max) }\end{array}$ & $40(4-110)$ & 0.066 \\
\hline
\end{tabular}

TABLE 2 - Perioperative factors in patients with CRLM submitted to liver resection with curative intent

\begin{tabular}{|c|c|c|}
\hline Variable & $\mathrm{n}(\%)$ & $p$ * \\
\hline Neoadjuvant chemotherapy & $65(89.0)$ & 0.058 \\
\hline $\begin{array}{l}\text { Hepatectomy } \\
\text { Minor } \\
\text { - Segmentectomy (up to three) } \\
\text { - Non-anatomical resections } \\
\text { Major } \\
\text { - Right hepatectomy } \\
\text { - Left hepatectomy } \\
\text { - Trisectionectomy } \\
\text { - Non-anatomical resections } \\
\text { - Segmentectomy (four or more) }\end{array}$ & $\begin{array}{c}40(54.8) \\
\cdot 36(49,3) \\
\cdot 4(5,4) \\
33(45.2) \\
\cdot 13(17.8) \\
\cdot 6(8.2) \\
\cdot 6(8.2) \\
\cdot 6(8.2) \\
\cdot 2(2.7)\end{array}$ & 0.421 \\
\hline Simultaneous colorectal resection & $8(11.0)$ & 0.686 \\
\hline Perioperative transfusion & $7(9.6)$ & 0.683 \\
\hline $\begin{array}{l}\text { Postoperative complications } \\
\text { (Clavien-Dindo classification) [16] } \\
\text { · } 0 \\
\cdot \text { I e II } \\
\cdot \text { III e IV } \\
\cdot \text { V }\end{array}$ & $\begin{array}{c}55(75.3) \\
13(17.8) \\
5(6.8) \\
0(0)\end{array}$ & 0.316 \\
\hline $\begin{array}{l}\text { Length of stay (days) } \\
\text { - Median (min-max) }\end{array}$ & $5(3-30)$ & 0.565 \\
\hline $\begin{array}{l}\text { Margin status } \\
\cdot>1 \mathrm{~mm} \\
\cdot>1 \mathrm{~mm}\end{array}$ & $\begin{array}{l}57(78.1) \\
16(21.9)\end{array}$ & 0.101 \\
\hline
\end{tabular}

TABLE 3 - Univariate analysis of prognostic factors after CRLM resection with curative intent

\begin{tabular}{|c|c|c|c|}
\hline Variable & $\begin{array}{l}\text { OS (months) } \\
\text { (P25; P75) }\end{array}$ & 5-year OS (\%) & $p^{*}$ \\
\hline $\begin{array}{l}\text { Location } \\
\cdot \text { Right-sided } \\
\cdot \text { Left-sided }\end{array}$ & $\begin{array}{l}41(27-54) \\
61(29-92)\end{array}$ & $\begin{array}{l}40.1 \% \\
52.7 \%\end{array}$ & 0.282 \\
\hline $\begin{array}{l}\text { T stage } \\
\cdot \text { T0-T2 } \\
\cdot \text { T3-T4 }\end{array}$ & $\begin{array}{c}89(60-119) \\
54(44-63)\end{array}$ & $\begin{array}{l}70.0 \% \\
44.7 \%\end{array}$ & 0.186 \\
\hline $\begin{array}{l}\mathrm{N} \text { stage } \\
\cdot \mathrm{NO} \\
\cdot \mathrm{N}+\end{array}$ & $\begin{array}{c}88(38-117) \\
50(38-61)\end{array}$ & $\begin{array}{l}64.0 \% \\
40.9 \%\end{array}$ & 0.228 \\
\hline $\begin{array}{l}\text { Tumor differentiation } \\
\cdot \text { Well/moderately } \\
\text { - Low/signet ring cell }\end{array}$ & $\begin{array}{c}55(23-86) \\
39(3-74)\end{array}$ & $\begin{array}{l}49.6 \% \\
22.2 \%\end{array}$ & 0.050 \\
\hline $\begin{array}{l}\text { Lymphovascular invasion } \\
\cdot \text { None } \\
\text { - Present }\end{array}$ & $\begin{array}{c}77(62-103) \\
48(24-61)\end{array}$ & $\begin{array}{l}71.7 \% \\
34.6 \%\end{array}$ & 0.021 \\
\hline $\begin{array}{l}\text { Perineural invasion } \\
\cdot \text { - None } \\
\text { - Present }\end{array}$ & $\begin{array}{c}83(44-121) \\
48(35-60)\end{array}$ & $\begin{array}{l}59.4 \% \\
37.5 \%\end{array}$ & 0.346 \\
\hline $\begin{array}{l}\text { Simultaneous colorectal resection } \\
\cdot \text { No } \\
\text { - Yes }\end{array}$ & $\begin{array}{l}55(26-83) \\
30(5-54)\end{array}$ & $\begin{array}{l}49.5 \% \\
42.9 \%\end{array}$ & 0.208 \\
\hline $\begin{array}{l}\text { CRLM classification } \\
\cdot \text { Synchronous } \\
\text { - Metachronous }\end{array}$ & $\begin{array}{l}47(38-55) \\
97(70-123)\end{array}$ & $\begin{array}{l}42.5 \% \\
64.6 \%\end{array}$ & 0.020 \\
\hline $\begin{array}{l}\text { Number of nodules } \\
\cdot 1 \\
\cdot 2-3 \\
\cdot=4\end{array}$ & $\begin{array}{c}83(37-128) \\
79(47-110) \\
33(28-37)\end{array}$ & $\begin{array}{l}58.3 \% \\
51.4 \% \\
17.3 \%\end{array}$ & 0.004 \\
\hline $\begin{array}{l}\text { Distribution } \\
\text { - Unilobar } \\
\text { - Bilobar }\end{array}$ & $\begin{array}{c}83(49-116) \\
47(32-61)\end{array}$ & $\begin{array}{l}61.3 \% \\
19.8 \%\end{array}$ & 0.019 \\
\hline $\begin{array}{l}\text { Diameter }(\mathrm{mm}) \\
\cdot<50 \mathrm{~mm} \\
\cdot=50 \mathrm{~mm}\end{array}$ & $\begin{array}{l}61(31-90) \\
41(25-56)\end{array}$ & $\begin{array}{l}51.6 \% \\
42.4 \%\end{array}$ & 0.027 \\
\hline $\begin{array}{l}\text { Neoadjuvant chemotherapy } \\
\cdot \text { No } \\
\text { - Yes }\end{array}$ & $\begin{array}{l}68(57-79) \\
55(26-83)\end{array}$ & $\begin{array}{l}64.3 \% \\
48.1 \%\end{array}$ & 0.480 \\
\hline $\begin{array}{l}\text { Hepatectomy } \\
\cdot \text { Minor } \\
\cdot \text { Major }\end{array}$ & $\begin{array}{c}92(28-115) \\
50(27-72)\end{array}$ & $\begin{array}{l}52.6 \% \\
45.4 \%\end{array}$ & 0.190 \\
\hline $\begin{array}{l}\text { Perioperative transfusion } \\
\cdot \text { No } \\
\cdot \text { Yes }\end{array}$ & $\begin{array}{c}88(26-126) \\
55(27-82)\end{array}$ & $\begin{array}{l}57.1 \% \\
48.5 \%\end{array}$ & 0.469 \\
\hline $\begin{array}{l}\text { Postoperative complications } \\
\text { (Clavien-Dindo classification) [16] } \\
\cdot 0, \text { I e II } \\
\cdot \text { III e IV }\end{array}$ & $\begin{array}{l}61(31-90) \\
39(19-58)\end{array}$ & $\begin{array}{l}50.0 \% \\
40.0 \%\end{array}$ & 0.300 \\
\hline $\begin{array}{l}\text { Margin status } \\
\cdot>1 \mathrm{~mm} \\
\cdot=<1 \mathrm{~mm}\end{array}$ & $\begin{array}{c}79(46-111) \\
44(33-54)\end{array}$ & $\begin{array}{l}54.2 \% \\
28.9 \%\end{array}$ & 0.164 \\
\hline
\end{tabular}

*=log-rank test; $C R L M=$ colorectal liver metastasis; $O S=$ overall survival; $P=$ percentile $\mathrm{mm}=$ millimeter

TABLE 4 - Multivariate analysis of prognostic factors after CRLM resection with curative intent

\begin{tabular}{|c|c|c|c|}
\hline Variable & HR & $\mathrm{Cl} 95 \%$ & $p$ \\
\hline $\begin{array}{l}\text { Tumor differentiation } \\
\text { · Well/moderately } \\
\text { - Low/signet ring cell }\end{array}$ & 2.9 & $0.840-10.437$ & 0.091 \\
\hline $\begin{array}{l}\text { Lymphovascular invasion } \\
\text { - None } \\
\text { - Present }\end{array}$ & - 2.7 & $1.106-6.768$ & 0.029 \\
\hline $\begin{array}{l}\text { CRLM classification } \\
\cdot \text { Synchronous } \\
\cdot \text { Metachronous }\end{array}$ & $\begin{array}{c}2.8 \\
-\end{array}$ & $1.069-7.365$ & 0.036 \\
\hline $\begin{array}{l}\text { Number of nodules } \\
\cdot<4 \\
\cdot=4\end{array}$ & $\begin{array}{c}- \\
1.7\end{array}$ & $1.046-2.967$ & 0.033 \\
\hline Diameter $>=50 \mathrm{~mm}$ & - & - & 0.361 \\
\hline $\begin{array}{l}\text { Hepatectomy } \\
\cdot \text { Minor } \\
\cdot \text { Major }\end{array}$ & - & - & 0.443 \\
\hline $\begin{array}{l}\text { Margin status } \\
\cdot>1 \mathrm{~mm} \\
\cdot=<1 \mathrm{~mm}\end{array}$ & - & - & 0.230 \\
\hline
\end{tabular}

$\mathrm{CRLM}=$ colorectal liver metastasis; $\mathrm{HR}=$ hazard ratio; $\mathrm{Cl}=$ confidence interval; $\mathrm{mm}=$ millimeter 
with survival after CRLM resections. In fact, these two variables were not associated with survival in our study.

Lymphovascular invasion in the colon or rectum, however was the single most significant prognostic factor related to the primary tumor after both univariate and multivariate analysis, with a HR of 2.7 ( $\mathrm{Cl} 95 \%$ 1.106-6.766; $p=0.029)$. This pathological finding is usually related to tumor grading, local invasion and local recurrence, though not frequently pointed out as an important factor related to the primary tumor in metastatic setting ${ }^{2}$. A retrospective study performed in 2012 corroborates these data showing a survival of 48 months in patients with lymphovascular invasion, compared to 69 months for those without it $(p<0,0001)^{5}$.

Regarding the metastatic disease, the occurrence of liver nodules within six months of diagnosis of the primary tumor was also an independent worse prognosis factor of survival. There is no consensus on the literature on the exact definition of a synchronous metastasis. It has been defined from only those diagnosed simultaneously with the primary as well as up to 30 months afterwards ${ }^{9,10,13,24,28}$. Because of these conceptual disparities, the impact of this factor on survival is also a matter of debate, and a few works have been unable to demonstrate its significance when using a cutoff of up to three months ${ }^{17,22}$. Despite this fact, synchronous metastasis either represent a delayed diagnosis or, more commonly, a more aggressive neoplasia with a worse tumor biology, hence, poorer prognosis. On the other hand, it is expected that metachronous metastasis are diagnosed earlier and possibly in small number and size.

The association of size, number and bilobar distribution of CRLM with survival is also straightforward and was significant after univariate analysis, even though only the number of four or more nodules have remained significant after multivariate analysis. In a resemblance of the above mentioned discussion on the synchronous definition, there is great variability on the cutoffs values of these variables ${ }^{10,11,13,19,21,22}$. Interestingly, the widespread indication of neoadjuvant therapy may have impacted the relevance of these factors on survival, since it is not uncommon for this patients to present with a shrinkage of the nodules and even its disappearance in follow-up imaging. A retrospective analysis by John et al. ${ }^{11}$ including 432 patients with an incidence of neoadjuvant chemotherapy of $60 \%$ has failed to demonstrate the impact of number and size on survival. In this case series $89 \%$ of patients has been submitted to neoadjuvant chemotherapy, a much higher number when compared to classical series that ranges from 0 to $60 \%$ of the cohort $17,21,30$.

Surgical resection margins under $1 \mathrm{~mm}$ were found in $21.9 \%$ of resections, but did not impacted on survival. The cut-off value of $1 \mathrm{~mm}$ for surgical margins is also a matter of debate in the literature, with an incidence of up to $37.8 \%$ of nodules being within this distance from liver transection ${ }^{14}$. The pathology assessment of resection margins can be highly compromised after liver resection due to carbonization and loss of the surrounding parenchyma, as well as fracture of the liver tissue during processing of the material, conceivably leading to a higher rate of positive margins ${ }^{19}$. However, a 2017 meta-analysis that enrolled 11147 patients regarding this matter demonstrated an improvement in 5- and 10-year overall survival rates when margins were $>1 \mathrm{~cm}$ distance from surgical transection line $(R R=0.91, p=0.003 ; R R=0.94, p=0.054 \text {, respectively })^{14}$. On the other hand, a series of works have questioned this impact when considering the relation of submillimeter resection margin with KRAS mutational status, adjuvant chemotherapy treatment and the size of the tumor assessed ${ }^{13,16,26}$.

The main limitations of this study can be attributed to its retrospective nature and the small sample size. The adjuvant chemotherapy regimens were also not assessed, possibly leading to different outcomes, as well as adjuvant chemotherapy for the primary tumor. Likewise, imaging follow-up of clinical response after neoadjuvant chemotherapy was not assessed in this study. Prospective studies with a greater number of patients are needed to better draw consensus on these prognostic factors, especially regarding the primary tumor.

\section{CONCLUSION}

The resection of liver metastases of colorectal adenocarcinoma leads to high survival rates of up to $64 \%$. A great number of factors are used in survival prediction, especially those related to the metastatic disease, but the assessment of lymphovascular invasion in the primary tumor is a widely available and easily assessed variable that significantly impacts survival.

\section{REFERENCES}

1. Abdalla EK, Vauthey JN, Ellis LM, Ellis V, Pollock R, Broglio KR, Hess K, Curley SA. Recurrence and Outcomes Following Hepatic Resection, RadiofrequencyAblation, and Combined Resection/AblationforColorectal Liver Metastasis. Annals of Surgery. 2004;239:818-827. https://doi. org/10.1097/01.sla.0000128305.90650.71.

2. Akagi Y, Adachi Y, Ohchi T, Kinugasa T, Shirouzu K. Prognostic impact of lymphatic invasion of colorectal cancer: a single-center analysis of 1616 patients over 24 years. Anticancer Research. 2013;33(7):2965-70.

3. Bengtsson G, Carlsson G, Hafstrom L, Jonsson PE. Natural history of patients with untreated liver metastasis from colorectal cancer. Am J Surg. 1981;141:586-9. https://doi.org/10.1016/0002-9610(81)90057-x.

4. Bustamante-Lopez LA, Nahas SC, Nahas CS, Pinto RA, Marques CFS, Cecconello I. Is there a difference between right and left-sided colon cancers? Does side make any difference in long-term follow-up? ABCD Arq Bras Cir Dig, 2019;32(4):e1479. https://doi.org/10.1590/0102$672020190001 \mathrm{e} 1479$.

5. Cardona K, Mastrodomenico P, D'Amico F, Shia J, Gönen M, Weiser MR, et al. Detailed pathologic characteristics of the primary colorectal tumor independently predictoutcomeafterhepatectomy formetastasis. Annals of Surgical Oncology. 2013;20(1):148-154. https://doi.org/10.1245/ s10434-012-2540-y.

6. Coimbra FJF, Ribeiro HSC, Marques MC, Herman P, Chojniak R, Kalil AN, et al. First Brazilian consensus on multimodal treatment of colorectal liver metastases. Module 1: Pre-treatment evaluation. ABCD Arq Bras Cir Dig. 2015;28(4):222-230. doi: 10.1590/S0102-6720201500040002.

7. Deng Y, Peng J, Zhao Y, Sui Q, Zhao R, Lu Z, Qiu M, Lin J, Pan Z. Lymph node ratio as a valuable prognostic factor for patients with colorectal liver-onlymetastasisundergoing curativeresection.CancerManagement and Research.2018;10:2083-2094.https://doi.org/10.2147/cmar.s169029.

8. Ferrarotto R, Pathak P, Maru D, Adarwal A, Overman M, Hoff PM, Kopetz S. Durable complete responses in metastatic colorectal cancer treated with chemotherapy alone. Clin Colorectal Cancer. 2011;10(3):178-182. https://doi.org/10.1016/j.clcc.2011.03.023.

9. Fong $Y$, Fortner J, Sun RL, Brennan MF, Blumgart LH. Clinical score for predicting recurrence after hepatic resection for metastatic colorectal cancer:analysis of 1001 consecutivecases.AnnalsofSurgery. 1999:230:309318. https://doi.org/10.1097/00000658-199909000-00004.

10. Iwatsuki S, Dvorchik I, Madariaga JR, Marsh JW, Dodson F, Bonham AC, GellerDA, Gayowski TJ, Fung J, StarzITE. Hepatic resection for metastatic colorectal adenocarcinoma: a proposal of a prognostic scoring system. Journal of American College of Surgeons. 1999;189: 291-299. https:// doi.org/10.1016/s1072-7515(99)00089-7.

11. John SKP, Robinson SM, Rehman S, Harrison B, Vallance A, French J, Jacques BC, Charnley RM, Manas DM, White SA. Prognostic Factors and Survival after Resection of Colorectal Liver Metastasis in the Era of Preoperative Chemotherapy: An 11-Year Single-Centre Study. Digestive Surgery. 2013;30:293-301. https://doi.org/10.1159/000354310.

12. Liu W, Wang HW, Wang K, Xing BC. The primary tumor location impacts survival outcome of colorectal liver metastasis after hepatic resection: a systematic review and meta-analysis. European Journal of Surgical Oncology.2019;45(8):1349-1356.https://doi.org/10.1016/j.ejso.2019.04.017.

13. Margonis GA, Sasaki K, Andreatos N, et al. KRAS mutation status dictates optimal surgical margin width in patients undergoing resection of colorectal liver metastasis. Annals of Surgical Oncology. 2017; 24:264271. https://doi.org/10.1245/s10434-016-5609-1.

14. Margonis GA, Sergentanis TN, Ntanasis-Stathopoulos I, Andreatos N Tzanninis IG, Sasaki K, Psaltopolou T, Wang J, Buettner S, Papalois AE, He J, Wolfgang CL, Pawlik TM, Weiss MJ. Impact of Surgical Margin Width on Recurrence and Overall Survival Following RO Hepatic Resection of Colorectal Metastasis: A Systematic Review and Meta-analysis. Annals of Surgery. 2018;267(6):1047-1055. https://doi.org/10.1097/ sla.0000000000002552.

15. MakowiecF, MenzelM, BronsertP, HolznerPA, KlockA, LangSA, FichtnerFeigl S, Neeff HP. Does the site of primary colorectal cancer influence the outcome after resection of isolated liver metastasis? Digestive and Liver Disease. 2018. https://doi.org/10.1016/j.dld.2018.06.019. 
16. Miller CL, Taylor MS, Qadan M, Deshpande V, Worthington S, Smalley R, Collura C, Ryan DP, Allen JN, Blaszkowsky LS, Clark JW, Murphy JE, Parikh AR, Berger D, Tanabe KK, Lillemoe KD, Ferrone CR. Prognostic Significance of Surgical Margin Size After Neoadjuvant FOLFOX and/ or FOLFIRI for Colorectal Liver Metastasis. Journal of Gastrointestinal Surgery.2017;21:1831-1840.https://doi.org/10.1007/s11605-017-3557-0.

17. Minagawa M, Makuuchi M, Torzilli G, Takayama T, Kawasaki S, Kosuge T, Yamamoto J, Imamura H. Extension of theFrontiers ofSurgical Indications in the Treatment of Liver Metastasis From Colorectal Cancer. Annals of Surgery. 2000;231(4):487-499. https://doi.org/10.1097/00000658200004000-00006.

18. Nordlinger B, Guiguet M, Vaillant JC, et al. Surgical resection of colorectal carcinomametastasis totheliver.Aprognosticscoring systemtoimprove caseselection, based on 1568 patients. Association Francaise deChirurgie. Cancer. 1996;77:1254-62. https://doi.org/ 10.1002/\%28SICI\%2910970142\%2819960401\%2977\%3A7\%3C1254\%3A\%3AAID-CNCR5\%3E3.0.CO\%3B2-

19. Nordlinger B, Vaillant JC, Guiguet M, Balladur P, Paris F, Bachellier $P$, Jaeck $D$. Survival benefit of repeat liver resections for recurrent colorectal metastasis: 143 cases. AssociationFrancaisedeChirurgie.Journal ofClinical Oncology.1994;12:1491-1496.https://doi.org/10.1200/jco.1994.12.7.1491.

20. Pawlik TM, Scoggins CR, Zorzi D, et al. Effect of surgical margin status on survivalandsiteofrecurrenceafterhepaticresectionforcolorectalmetastasis. Annals ofSurgery.2005;241:715-722. https://dx.doi.org/10.1097\%2F01. sla.0000160703.75808.7d.

21. Rees M, Tekkis PP, Welsh FKS, O'Rourke T, John TG. Evaluation of Longterm Survival After Hepatic Resection for Metastatic Colorectal Cancer: A Multifactorial Model of 929 Patients. Annals of Surgery. 2008;247(1):125135. https://doi.org/10.1097/sla.0b013e31815aa2c2.

22. Reissfelder C, Rahbari NN, Koch M, Ulrich A, Pfeilschifter I, Waltert A Müller SA, Schemmer P, Büchler MW, Weitz J. Validation of Prognostic Scoring Systems for Patients Undergoing Resection of Colorectal Cancer LiverMetastasis.AnnalsofSurgicalOncology.2009;16:3279-3288.https:// doi.org/10.1245/s10434-009-0654-7.

23. RibeiroHSC, Stevanato-FilhoPR, CostaJrWL, DinizAL, HermanP, Coimbra FJF.Prognosticfactorsin patientswithcolorectal livermetastasis: experience of a single Brazilian cancer center. Arquivos de Gastroenterologia. 2012;49(4):266-272.http://dx.doi.org/10.1590/S0004-28032012000400007.
24. Ribeiro HSC, Torres OJMT, Marques MC, Herman P, Kalil AN, Fernandes ESM, etal. FirstBrazilianconsensus on multimodal treatment of colorectal liver metastases. Module 2: approach to resectable metastases. ABCD ArqBras CirDig.2016;29(1):9-13.doi:10.1590/0102-6720201600010003.

25. Sasaki K, Margonis GA, Maitani K, Andreatos N, Wang J, Pikoulis E, He J, Wolfgang CL, Weiss M, Pawlik TM. The Prognostic Impact of Determining Resection Margin Status for Multiple Colorectal Metastasis According to the Margin of the Largest Lesion. Annals of Surgical Oncology. 2017;24(9):2438-2446. https://doi.org/10.1245/s10434-017-5904-5.

26. Simmonds PC, Primrose JN, ColquittJL, Garden OJ, Poston GJ, Rees M. Surgical resection ofhepaticmetastasisfrom colorectalcancer:Asystematic review of published studies. British Journal of Cancer. 2006;94,982-999. https://dx.doi.org/10.1038\%2Fsj.bjc.6603033.

27. Wagle P, Narkhede R, Desai G, Pande P, Kulkarni DR, Varty P. Surgical Management of large hepatocellular carcinoma: the first single-center study from western india. ABCD Arq Bras Cir Dig. 2020;33(2):e1505.

28. Wang XY, Zhang R, Wang Z, Geng Y, Lin J, Ma K, et al. Meta-analysis of the association between primary tumour location and prognosis after surgical resection of colorectal liver metastasis. British Journal of Surgery. 2019;106(13):1747-1760. https://doi.org/10.1002/bjs.11289.

29. Wei AC, Greig PD, Grant D, Taylor B, Langer B, Gallinger S. Survival After Hepatic Resection forColorectal Metastasis:A 10-YearExperience.Annals of Surgical Oncology. 2006;13(5):668-676. https://doi.org/10.1245/ aso.2006.05.039.

30. Yamashita S, Brudvik KW, Kopetz SE, Maru D, Clarke CN, Passot G, et al. Embryonic origin of primary colon cancer predicts pathologic response and survival in patients undergoing resection for colon cancer liver metastasis. Annals of Surgery. 2018;267(3):514-520. https://doi. org/10.1097/sla.0000000000002087.

31. Zakaria S, Donohue JH, Que FG, Farnell MB, Schleck CD, Ilstrup DM, Nagorney DM. Hepatic Resection for Colorectal Metastasis: Value for Risk Scoring Systems? Annals of Surgery. 2007;246:183-191. https://doi. org/10.1097/sla.0b013e3180603039. 